\title{
People with Lobster - Claw Syndrome: A Study of Oligodactyly Sufferers and their Communication Experiences in the Village of Ulutaue, South Sulawesi, Indonesia
}

\author{
Deddy Mulyana \\ Padjadjaran University, Jatinangor, West Java, Indonesia
}

Sulaeman

State Islamic Institute, Ambon, Indonesia

Doi:10.5901/mjss.2016.v7n1s1p136

\begin{abstract}
Oligodactyly is the multiple malformation of hands and feet since birth. This study pertains to how 15 people suffering from Oligodactyly in the Village of Ulutaue, South Sulawesi, Indonesia, have constructed the meaning of their ailments and how they have communicated with people without disabilities around them in their daily lives. The study is based on a social construction perspective and a symbolic interactionist perspective, with the research method of in-depth interviews. Based on their accounts, we have developed a typology of Oligodactyly sufferers, meaning construction and themes related to their communication experiences. They considered their suffering in terms of having a different body, a body cursed by God, and the body as God's bounty. The sufferers have been abandoned and discriminated against by their immediate families as well as people outside their families. The way nondisabled people treated them created difficulties for them to survive within society and to be free from their existing agony.
\end{abstract}

Keywords: Oligodactyly, communication experiences, social construction, symbolic interactionist perspective.

\section{Research Background}

Indonesia is a developing country with a population of over a quarter of a billion people. Health problems are omnipresent. The country lacks adequate medical facilities and the government does not pay sufficient attention to people in need of medical treatment. A larger proportion of Indonesians seek alternative healthcare beyond westernized medical treatment. Some people use a naturalistic approach to cure their ailments, such as consuming herbal medicine, getting massages or acupuncture. Others visit clergymen or even shamans in the hopes that they can get better. For handicapped people, the situation is dire. Indonesia lacks suitable public transport, special stairways and lifts, toilets, and suitable recreation and sport facilities for the disabled. Those who suffer from bodily abnormalities have attracted little attention, especially people afflicted with leprosy and Oligodactyly.

By definition, Oligodactyly is the condition of fewer than five fingers or toes on a hand or foot. Biomedical specialists such as Robinow et al. (1986) and Turnpenny et al. (1992) have investigated those deformities from a clinical and genetic perspective. However, fewer investigations on the social implications of this ailment have been carried out, let alone in Indonesia. This research is aimed to fill in this wide research gap. From a social perspective, Oligodactyly is not merely a disease, but it is also an illness that may affect the psychological condition of the sufferers and their interaction with people around them. The stigma attributed by nondisabled people to disabled people, including Oligodactyly sufferers, is like a vicious circle, partly dependent on how nondisabled people treat them. The worse the treatment, the worse their psychological condition. By understanding their sufferings and subjective experiences, we can empathize more with them, so that they are more motivated to enhance their lives.

\section{Aims of Study and Research Method}

This research aims to delineate how the sufferers of Oligodactyly have constructed the meaning of their ailments and how they have communicated with nondisabled people around them in the Village of Ulutaue, South Sulawesi, Indonesia.

This study is part of larger research which lasted almost two years, from 2012 to 2014 . The study involved 15 Oligodactyly sufferers consisting of 10 males and five females suffering from Oligodactyly. Their ages ranged from 10 to 73 at the time of the research. Ten sufferers were still single, while others were married. Fourteen sufferers had jobs, 
mostly self-employed, especially as sea pickers (by picking small shrimps, small oysters, and sea weed) from the shore and only one sufferer was unemployed. To protect the identities of the sufferers, we use pseudonyms in this research paper.

Most of the Oligodactyly sufferers had never been formally educated at school, so they were not able to count, read or write. Most of the sufferers had three fingers on each of their hands and three toes on each of their feet. There were a few sufferers who had two or four fingers or two or four toes on each of their hands or feet. Such hands and feet seem very different from normal hands and feet that people see in everyday life.

To gain the data for this research, we have conducted in-depth interviews, on different dates. Most of the interviews took place in seashores where the interviewees were working. Some interviews took place in their homes, at school, and near a dam. Each sufferer was interviewed between three to five times, so four times on an average, with the duration of each interview between 50 to 90 minutes.

Initially, making the interviews was not easy as the Oligodactyly sufferers regarded us as journalists who would take advantage of them by reporting their life stories to readers. Even, when they were willing to be interviewed, the sufferers seemed uneasy, especially at the beginning. However, we were able to gather data from the sufferers, as we always indicated our patience and empathy toward them. In many cases, the interviews flowed smoothly. The interviews were facilitated by the fact that one of the researchers knew and used their local language, enabling the interviews to be conducted intimately. Basically we asked each sufferer similar questions, although the sequence of the questions was not always the same.

\section{Theoretical Perspective}

Many researchers have employed the objective-scientific (biomedical) perspective to investigate healthcare (health communication and therapeutic communication) based on the assumption that there are regularities in social reality and hence in human behavior in relation to healthcare. Its adherents aim to propose general laws by specifying and predicting causal relationships or correlations between variables. Therefore, such positivists frequently begin their research with hypotheses, then follow with statistical analysis. Their research methods apparently provide narrower and less humanistic knowledge no matter how sophisticated and accurate they are. Such empirical works have been done, for instance, by Gibson and Zhong (2005), Lee (2008), Primack et al. (2009), and Brown and De Matviuk (2010). In Indonesia this kind of research includes the following works: Iba (2005) who investigated the relationships between the paramedic people's communication and patients' attitudes toward medical services in the Provincial Public Hospital in Southeast Sulawesi; Dida (2011) who investigated the influence of optimalization in health communication at the Basic Health Center on the level of children's wellbeing in West Java; and Agustini (2012) who investigated the effects of service marketing communication on the patients' perception of the Emma Poeradiredja Hospital in Bandung.

In contrast with the quantitative-statistical research above, our research is qualitative in nature, exploring individuals' interpretation of their Oligodactyly sufferings and their social experiences with people in their environment. To that end, we use an interpretive perspective, or more specifically, a social construction perspective and a symbolic interactionist perspective, both of which should be considered as complementary to each other. Both theoretical perspectives stipulate that individuals determine their own goals in life. They are active, creative, and innovative in interacting with others. The individuals' actions have resulted from their definition of their immediate situation, not as a result from external factors. In this context, reality is considered as intersubjective, shared, and negotiated. Simply speaking, actors adjust their own actions to fit in with others' actions.

To use Berger and Luckmann's perspective (1966), the social construction of reality is a symbolic interplay between an actor's own consciousness and the consciousness of other actors in their shared life. Using the symbolic interactionist theory, individuals' actions are based on their definition of a person, an object or the environment they confront, and they may change their actions based on their interpretation of others' actions (Blumer, 1969). Based on such theoretical assumptions, we would like to explore how the sufferers of Oligodactyly use their own accounts to look at their ailments, and how they communicate with people around them in their everyday lives. As Marks et al. (2000:6) point out, "People's accounts of health and illness are interesting and illuminating topics of study in their own right."

Viewed from an interpretive perspective, people suffering from Oligodactyly may give certain meanings to their illness constructed from social attitudes around them and may engage in certain ways of communication with others. This interpretive perspective is considered to be suitable and more holistic in order to investigate the actors' unique experiences. In other words, illness is considered not as merely physical symptoms but mainly as subjective experiences. It is the individuals' personal accounts of their ailments, not the ailments as defined objectively by scientific or medical parameters, which matter here. 
Oligodactyly may be assumed by medical doctors and nurses solely as a disease, that is, an objective reality (physical or organic symptoms) that can be diagnosed and examined in clinics or laboratories. However, we contend that for the purpose of this research, Oligodactyly should be considered as illness rather than disease. Kleinman et al. (cited in Scharf and Vanderford, 2003:14) defines a disease as "organic malfunctions and pathological processes whose signs and symptoms typically can be observed and quantitatively assessed," while illness is "the patient's experience of disease or ill health". In the same vein, Eisenberg (cited in Hardey, 1998:29) maintains,

"Patients suffer 'illnesses'; physicians diagnose and treat 'disease'. Illnesses are experiences of disvalued changes in states of being and social function: diseases are abnormalities in the structure and function of body organs and systems"

There has been a lot of research on healthcare based on the social construction theory (often associated with phenomenological theory and the symbolic interactionist theory). This overwhelming research includes the following works: Davis (1972), Musgrove (1977, Chapters 5 \& 6), Vittoria (1999), Nguyen (2006), Kovarsky et al. (2007), Hinojosa et al. (2008), and Binder et al. (2012). In Indonesia research into health communication based on the social construction theory includes the following: Teja (2006) who investigated patients' social construction of leprosy at the Sinatala Hospital in Tangerang; Kadri (2007) who investigated the social construction of blindness in the Wyata Guna Residence in Bandung; Hadisiwi (2011) who explored the meaning of Filariasis as constructed by those who suffered from such illness in Bandung Regency; and Hafiar (2012) who explored the phenomenological experiences of disabled athletes in Bandung. Each of these studies is unique as it explores the deep feelings of the subjects which vary from one group of subjects to another. Kadri found, for instance, that the identity transformation of blind people underwent through five stages: internal self-shock, self-isolation, self-openness, self-improvement, and self-subjugation. Hadisiwi found that the sufferers of Filariasis defined themselves in four categories: Those with resignation, those with despair, those who never surrender, and those who feel as if they have no illness. People suffering from Filariasis interpreted their ailments as selfhumiliating and to be pitied, but in some cases as a driving spirit. Meanwhile, Hafiar discovered that the excelled disabled athletes had special identities which distinguished them from other disabled people; they gained more respect and were regarded as people with a better quality of life who could be taken as significant role models.

Based on the phenomenological perspective, Oligodactily is assumed to have been experienced as a subjective reality, not only as a bodily or physical experience. In this context, the illness experience may be connected with one's personal, social and cultural beliefs and values. Therefore more attention should be paid to the actors' personal interpretation of their ailments although it may also be related to socio-cultural factors rather than to their physical condition alone.

\section{Research Findings}

\subsection{Difficulties in Doing Routines}

Mundane life has different meaning and significance to different individuals. Even routine activities considered to be easy by a group of people may be regarded as complicated by others, as in the case with people who suffered from Oligodactyly in the Ulutaue Village. These people clearly had difficult lives physically, economically, socially, and psychologically in their everyday lives. The seemingly easy tasks but difficult for the Olygodactyly sufferers include the following:

- Eating rice with bare hands; rice continuously fell through their fingers

- Holding small objects such as glasses and plates; sufferers often dropped these utensils unintentionally and broke them.

- Drinking a glass of water with trembling fingers.

- Going outside just to get in the sun. Even though when they were in the sun, some of them got sick easily.

- Working as sea pickers; due to their deformed hands and feet, it was difficult for them to pick small shrimps, small oysters and sea weeds, and to work as assistants to fishermen.

- Selling the products in markets. Nondisabled people were reluctant to buy products from people whom they considered frightening and worried that the products were contaminated.

The Oligodactyly sufferers felt a kind of helplessness that others took pity on them. They needed some empathy from people without disabilities, although they would not refuse any assistance given to them, such as money, food, and facilities from authorities in charge of disabled people and poor people in general. Oligodactyly sufferers in the village 
were all low-educated due to their poor condition. Their low education also led to their limited interaction with nondisabled people, and to their limited choice of work. Many of them felt ashamed, inferior, and scared to meet strangers. They often lowered their heads or looked away to avoid the stares of others.

\subsection{The Conception of the Bodily Defects}

Among Oligodactyly sufferers under investigation, there are three different ways of conceiving their bodily abnormality: the different body, the body cursed by God, and the body as God's bounty. These different perceptions should not be considered as mutually exclusive. Rather, they simply suggest different attitudinal tendencies.

The Different Body. In the early age all the Oligodactyly sufferers expressed awareness of deformities. Some sufferers said that the bodies they had were just different from other normal bodies of people in general. They held such conception through different and special treatments they received from their parents as their significant others, for example, by buying them certain sandals to cover their deformed feet. In their adulthood, some of the sufferers still held such a view without associating the ailments with any metaphysical factors. The sufferers felt unlucky that they had had such deformed hands and feet since birth, the fate they could never change. They were aware that their physical condition made nondisabled people feel pity, or were scared, and even disgusted, that the sufferers wanted to run away from them or to avoid encounters with them.

Most of the Olygodactyly sufferers had negative feelings, at least in the past, although these negative feelings had been reinterpreted by some of the sufferers in terms of the present. They felt ashamed, sad, disappointed, pessimistic, depressed, inferior, desperate, traumatic, submissive, angry, close minded, and lazy. They blamed themselves for having no hope in life. Being aware of such an unfavorable fate, the sufferers were ashamed in front of nondisabled people, especially those of the opposite sex. This feeling of shame encouraged them to walk fast when they were outside their homes, especially on roads, and they avoided interaction with other people around them. The following quotations represent some of such unfavorable feelings:

"I am poor. I have uncertain jobs, sometimes as a picker of seaweeds and oysters. I sell the seaweeds in the market to buy cigarettes, and I bring the oysters home for my meals. I often feel hungry, as I have nothing to eat. I am physically handicapped. I want to work in the sea to do fishing, but I do not have a boat. I want to be a servant of fishermen, but I am ignored. I am different from them. Even if I can catch fish, people will not buy the fish I have caught because I am disgusting, as people say" (Ulhadi, M, 32)

"Why is life like this? Life cannot be changed. This life is exhausting and disappointing as I am physically handicapped. I cannot make my life and my family's life better" (Kaharuddin, M, 47).

"I feel ashamed. My friends shouted, 'Do not come close, as you have naughty fingers'. What they meant by 'naughty fingers' was 'less normal fingers'. They asked me to go away and not to play and to get together with them. I must accept this condition with the hope that someday they will not treat me like that anymore" (Subaco, M, 13).

The sufferers knew that people without disabilities would not approach them, let alone interact with them intimately. It was beyond their imagination that nondisabled people would marry them, except in a few cases in which the sufferers had some special expertise, for example as traditional healers. Some sufferers once involved in relationships with the opposite sex were disillusioned when their partners rejected them without sound reasons. This romantic failure was experienced for instance by Renita $(F, 35)$ and Abditiro $(M, 35)$. A female partner criticized Abditiro as a useless man who would not make women happy.

"I had been meaning to make close relationships with women, but I always failed. At the beginning a woman liked me, but left me at last when she found that I have a handicap with my hands and feet. I felt degraded and ashamed. But it does not matter. I have to make efforts again to find a woman who can accept me the way I am" (Abditiro)

One female sufferer, Cahaya $(F, 52)$, was even abandoned by her husband (who had been married to her for 10 years) without a sound reason.

"I feel inferior because he left us as his family. He left without a cause. I have been abandoned by my husband since our second child was born. As a wife I have a heavy responsibility. My child also has the same condition of fingers and toes" (Cahaya) 
The Body Cursed by God. Of the Oligodactyly sufferers interviewed, some maintained that the illness was due to the curse of God. They associated their illness with the failures or the sins committed by their families, parents, grandparents, or even by their ancestors. They thought that their illness was probably caused by the negative attitudes of those people toward others in their past social life, especially by boasting themselves as being superior in status and physical appearance while looking down on others.

- "My parents used to look down on other women" (Ambo Asse, M, 73)

- "My grandmother used to insult other people" (Gambur, M, 27)

- "My grandmother used to think she was more beautiful than other women" (Renita)

The Oligodactyly sufferers' perception of their illness is similar to the perception of leprosy sufferers in Tangerang as found by Teja (2006). Teja delineated that the dominant factor causing the leprosy as perceived by the sufferers was God's curse of them, although they hardly ever associated the curse with the faults of their parents or their ancestors.

The Body as God's Bounty. Most of Oligodactyly sufferers confessed that in the past they were desperate and depressed that they wanted to commit suicide. However, as time went by, some of them sincerely accepted their physical condition. They strived to be patient, strong, steadfast, hardworking, and optimistic. They were inclined to consider their bodily defects not as an obstacle but as a potential to develop meaningful relationships with others. They even emphasized that the abnormality of their hands and feet and their poor economic condition was a bounty from God. They said that their agony brought them blessings in disguise, which include the following:

- Physical strength. The sufferers seemed stronger than people without disabilities. They were continually working; they never looked tired in working.

- Physical immunity. They seldom suffered from other diseases, except for their deformed hands and feet. One sufferer, Ambo Asse, claimed that when he was a child and fell down from a high tree, he was all right. He also claimed that sharp tools could not hurt him.

- Ability to read other people's minds. The sufferers knew what would happen through their dreams.

- Having spouses who were physically normal, having durable households

- Having the ability to work as Paraji, that is, traditional healers as in the case with Ambo Asse, Renita, and Kaharuddin. They inherited the expertise to cure people from their parents. These people were considered as having supernatural powers with which to give favors to the environment, for example, by leading the ritual Mappare lise tasi in the village. In this ritual people feed the sea by bringing tuli (food) composed of colorful rice, eggs, banana leaves as the cover of the food, sirih leaves and a money (Rp. 1000,-) folded with the sirih leaves. Through this ritual, it is expected that the fishermen were given safety and much sustenance by pajjagatasi (the sea god).

Based on the Oligodactyly sufferers' accounts, it is clear that their past illness experiences have been reinterpreted in terms of the present reality, despite the fact that they were still suffering from the same illness. Indeed, Schutz (1972:74) confirms the significance of temporality in the social construction of reality: individuals give meaning to an event only after it has occurred; the meaning of an event is primarily retrospective. Based on the present perspective, the sufferers' past experiences are explicable.

"My husband married me when I was 19. He was good looking, a virgin and physically normal. How come I got a husband like that. It was a gift for a physically handicapped woman like me" (Matahari, F, 30)

"My physical condition is not perfect like others'. But I have been granted a mind to complement my weakness. Finally I am able to predict and to find out what other people are thinking. In addition, my body is strong. I never feel tired to work. Although I have a physical handicap, it is a gift from God. I accept it sincerely. I have been given a long span of life. I have been granted several children and grandchildren. They often visit me to entertain me" (Ambo Asse)

"I often cure people suffering from illness in this village. People think that I have a kind of superiority due to my deformed hands. I usually cure people on Friday" (Kaharuddin) .

The sufferers felt that in spite of their severe ailments, they also had respected positions in the eyes of others, at least those who needed their help as traditional healers. The research found that these traditional healers were well known not only in their own village, but also in other villages. They were assumed by some villagers as more credible than medical providers. According to the sufferers, in the eyes of others, they had that expertise because they had deformed fingers and toes. 


\title{
5. Verbal and Nonverbal Insults
}

In their communication with people without disabilities around them, Oligodactyly sufferers were often offended not only by strangers but also by acquaintances, neighbors, and even by relatives and family members. Some observers or visitors just gave negative comments but not with the intention to insult them, while others insulted them intentionally. They were labeled as "people with fingers and toes that have branches," "frightening people," or "disgusting people." These verbal insults made them feel uncomfortable.

Apart from being verbally insulted, the sufferers were often looked down upon, mocked at, laughed at, and excluded by others. Incidental observers often spit or closed their noses and mouths with their hands when seeing the dirty and rumpled appearance of the sufferers, and their deformed hands and feet, in the hope not to smell the deformed hands and feet which they believed might be contagious.

\begin{abstract}
One afternoon I was riding a motor bike with my wife on the back. Passing by neighbors, one suddenly laughed, looked at me, and shouted 'Aju mappaka' (fingers that have branches). My wife held my chest so that I could accept such an insult" (Kaharuddin)
\end{abstract}

Such verbal and nonverbal insults were also experienced by Subaco, Rahmat M, 10), Ulhadi, and Nurhalijah (F, 13). When Subaco and Rahmat were going shopping to buy clothes, a woman closed her mouth with her hand and spit. She left the store without buying the clothes she was looking at. In another case, when Ulhadi and Nulhalijah were entering a store, some visitors also closed their mouths with their hands and spit. The store owner moved away and said, "What smell is this? There is garbage in this store."

\section{Treatment and Discrimination by Others}

People respond to our messages partly depending on who we are and how we appear before others. Names, looks, attire, body postures, all matter in communication. That the sufferers suffered from the malformation of hands and feet was clearly visible. Such deformed physical condition as compared with normal and functional bodily organs led the sufferers to feel a stigma and a sense of inferiority. The concept of the looking-glass self, once coined by Cooley (1983:184), is validated that people's self-concept is significantly determined by what they think others think of them, thus emphasizing the significance of subjectively interpreted responses as a primary source of data about the self. Simply put, what one internalizes as one's own derives from messages one receives from others.

Cooley contends that the nature of self-feeling is social, since its meaning is developed by shared language and culture. People's subjective interpretations of self are based on value Judgments that significant others make about their attributes and actions. In the context of this study, others make judgments about the sufferers' malformation of hands and feet.

In their communication with other people, most Oligodactyly sufferers considered that the way other people had communicated with them was weakening their spirit to survive. Once in a while, some of the sufferers were taken as beggars, because of their deformed hands and feet and their dirty and rumpled appearance. The following are some of the treatment the sufferers received from other people:

- Some people, even parents, siblings, in-laws, grandparents, and other relatives, refused or ignored the sufferers' existence, as if the sufferers were not alive (nonself). Those people did not talk much to the sufferers. Even when they talked to the sufferers, they often discriminated against them. Consequently, those sufferers themselves resigned from communication with others.

- Other parties, especially the local government and its lower authorities in charge of helping the disabled people, took pity on them to the extent that they were regarded as a burden to others. The sufferers were fed up with the promises given by the authorities that some assistance would be given but it was never realized.

- Television journalists came to meet the sufferers not primarily to understand them but to portray them as objects or commodity worthy of being reported and sold to television audiences. Having been described as "people who have fingers and toes like lobster claws" in a private television program, the sufferers resisted being covered by subsequent television journalists. For some time some of the sufferers also refused to be visited by groups of people who wanted to give them some sympathy or assistance, as Renita who rejected the visit of a group of Senior High School students.

One's perception of other people often determines a certain style of communication with them, whether intentionally or unintentionally. Seeing Oligodactyly sufferers as strange people, many nondisabled people often 
discriminated against them. Such discrimination comes not only from outsiders but also from one's immediate family, extended family, relatives, neighbors, and friends.

"I was waiting for a public transport vehicle in Bone to go home. One car stopped in front of me. But the driver said, "The car does not go to Mare." A passenger in the car shouted that I should not get in the car. That situation made me feel hurt. They should have taken pity on me" (Abditiro).

"When I saw my friends swimming in the sea, I approached them. I was also swimming. However, my friends did not want to swim with me. They moved away so that I was swimming alone" (Antokaseng, M, 10).

"Father asked me to stay at home, but asked the rest of my family to go to the market" (Nurhalijah).

"My husband's treatment of me is different from his treatment of his younger sibling. My husband rarely talks with me. He is somewhat indifferent to me. He talks more with his younger sibling. When my husband summons me, I pretend not to hear his summons. My mother in-law also rarely talks with me. When I visit my mother in-law, I feel like a stupid person. My in-laws also rarely talk with me, although there are a lot of people in my parents in law's house" (Nahriah, $F$, 27)

Most people the Oligodactyly sufferers encountered looked at them as strange people, as if they were inanimate objects that had no souls. In other words, they were taken as deviants. Frequently nondisabled people stared at them, looked away, and even went away without saying one word. The sufferers felt this kind of treatment especially in markets where they could make money. Nondisabled people were reluctant to buy the products sold by the sufferers. Serving so few buyers, the sufferers made little money.

\section{Discussion and Conclusion}

The Oligodactyly sufferers under this study have constructed the meaning of their ailments in different ways. Some sufferers viewed their defected body just as a different body, while others considered their deformed hands and feet as God's curse, and still others regarded their ailments as God's bounty. Some sufferers still regretted their unlucky fate deeply at the time of the research, while others saw some blessings behind the ailments.

In terms of gender, the female sufferers seemed to suffer from Oligodactyly psychologically more than the male sufferers due the stigma attributed by nondisabled people. Women in the village of Ulutaue were more dependent on men and on the family, rather than the other way around. Men suffering from Oligodactyly were more likely to marry nondisabled women, especially if the men had expertise that could be used to maintain the family. In terms of age, the younger the sufferers, especially those who were still single, the more intense the suffering. Simply put, the younger sufferers seem to be more depressed than the older ones. This tendency is partly due to the fact that the younger sufferers had greater needs to be accepted by their peers, and if possible, as prospective spouses. It is our assumption that if the sufferers had received optimal psychological and emotional support from their immediate families and relatives, they would have had more positive self-concepts and less negative reactions toward nondisabled people.

The Oligodactyly sufferers of the study interacted in many different ways of communication with people around them, although most of them indicated a similar tendency, that is, a withdrawal from others' presence and their preference to be left alone. They were aware that they were people to be avoided by people without disabilities in the daily social intercourse. The research has found that the dominant negative messages the sufferers received and internalized from their immediate family members, relatives and nonfamily members have weakened their spirit to survive.

In this research the social construction theory and the theory of symbolic interaction has been useful in exploring the experiences of the Oligodactyly sufferers. To some degree, the way the sufferers have defined their physical condition and the way they looked at themselves have been molded by the way others have treated them, although some of the sufferers have redefined their illness and their self-concept in a more creative way, especially those who have considered their illness as God's bounty.

Many people in the village considered the sufferers as people always in need that should be facilitated by others. This was not always the case. The crux of the problem is that the labels given by family members, nonfamily members, authorities and journalists, that the sufferers were "useless people," "disgusting people," "a social burden," or "the people with lobster claws" have created a vicious circle, or in a more scientific sense, "self-fulfilling prophecy," a prediction that becomes a reality because, whether we realize it or not what we believe will become a reality (Verderber, 1996:37). Using Lemert's perspective (cited in Musgrove, 1977:23), "In more extreme labeling theory the process of becoming deviant 
appears ineluctable; deviants lose individuality and become like empty organisms who are successfully labeled by others". Thus, the Oligodactyly sufferers became inferior and powerless because they had been labeled as such by others. Put differently, they were suffering from a social stigma, that is, an attribute that is deeply discrediting, reducing bearer "from a whole and usual person to a tainted, discounted one" (Goffman, 1963:3). In line with Goffman's perspective, this stigma is a spoiled identity based on feelings about self in relationships with nondisabled people.

This research has dealt with few aspects of the Oligodactyly sufferers' life experiences. Further studies with more sufferers will hopefully bring about more conclusive results. One of the limitations of this study is that it is based on a relatively few (15) sufferers from diverse (gender and age) backgrounds, although they were interviewed thoroughly, that it is somewhat risky to come up with generalizations.

Many other aspects are worth investigating, one of which is how the sufferers have presented themselves to neutralize the stigma they have received from other people, especially strangers. It has been found, for example, that they have used certain models of sandals to hide their deformed feet. So, using a dramaturgical perspective, we can explore what verbal and nonverbal tactics have been employed by the Oligodactyly sufferers to minimize the feeling of shame or inferiority before others or to cultivate a better image in front of others. We also wonder how the stigma associated with Oligodactyly differ from stigma associated with other defects or diseases or whether there are different kinds of stigma as felt by Oligodactyly sufferers. The answers to these questions are beyond our discussion at this time.

\section{Acknowledgements}

We would like to express our sincere gratitude to Peter Morse, Carolyn Calloway-Thomas, and Arielle Emmett for their comments on earlier drafts of this article.

\section{References}

Agustini, Prima M. 2012. Pengaruh Komunikasi Pemasaran Jasa Terhadap Pencitraan Pasien Mengenai Rumah Sakit Bersalin Emma Poeradiredja: Survei Eksplanatori mengenai Pengaruh Komunikasi Pemasaran Jasa terhadap Pencitraan Pasien Mengenai Rumah Sakit Bersalin Emma Poeradiredja Melalui Risiko, Kualitas Jasa, dan Posisi Jasa yang Diterima Pasien Periode JuniSeptember 2011 di Kota Bandung. [The Effect of Service Marketing on Patients' Perception of Maternity Hospital Emma Poeradiredja in Terms of Risk, Service Quality, and Service Position Received by Patients in the Period of June - September 2011]. Unpublished Doctoral Dissertation Padjadjaran University.

Berger, Peter L. and Thomas Luckmann. 1966. The Social Construction of Reality. Englewood Cliffs, N.J. Prentice-Hall.

Binder, Pauline, Yan Borne, Sara Johnsdotter, and Brigitta Esse'n. 2012. "Shared Language Is Essential: Communication in a Multiethnic Obstetric Care Setting." Journal of Health Communication 17, pp.1171-1186.

Blumer, Herbert. 1969. Symbolic Interactionism: Perspective and Method. Englewood Cliffs, N.J.: Prentice-Hall.

Brown, William J. and Marcela AC De Matviuk. 2010. "Sports Celebrities and Public Health: Diego Maradona's Influence on Drug Use Prevention." Journal of Health Communication 16, pp.726-749

Cooley, Charles H. 1983. Human Nature and the Social Order. New Brunswick: Transaction Books.

Davis, Fred. 1972. Illness, Interaction, and the Self. Belmont: Wadsworth.

Dida, Susanne. 2011. Pengaruh Optimalisasi Komunikasi Kesehatan pada Pusat Pelayanan Kesehatan Dasar terhadap Peningkatan Derajat Kesehatan Anak Usia Dini [The Effect of the Optimization of Health Communication by the Center of Basic Health Services on the Improvement of Early Aged Children's Health]. Unpublished Doctoral Dissertation Padjadjaran University.

Gibson, DeWan and Mei Zhong. 2005. "Intercultural Communication Competence in the Healthcare Context." International Journal of Intercultural Relations 29, pp. 621-634.

Goffman, Erving. 1963. Stigma: Notes on the Management of Spoiled Identity. Harmondsworth: Penguin.

Hadisiwi, Purwanti. 2011. Konstruksi Makna Penyandang Filariasis: Studi Fenomenologi tentang Konstruksi Makna Penyandang Filariasis dalam Komunikasi Risiko Kesehatan di Kabupaten Bandung [Meaning Construction of Elephantiasis Sufferers: $A$ Phenomenological Study of Meaning Construction by Elephantiasis Sufferers in the Context of Health Risk Communication in Bandung Regency]. Unpublished Doctoral Dissertation Padjadjaran University.

Hafiar, Hanny. 2012. Cacat dan Prestasi Melalui Pengalaman Komunikasi Atlet Penyandang Cacat: Studi Fenomenologi Mengenai Konstruksi Makna Kecacatan dan Status sebagai Atlet Berprestasi Melalui Pengalaman Komunikasi Atlet Penyandang Cacat Berprestasi di Bandung. [Disability and Achievement Experienced and Communicated by Disable Athletes: A Phenomenological Study about the Meaning Construction of Disability and Status as Experienced and Communicated by Disable High Achievers in Bandung]. Unpublished Doctoral Dissertation Padjadjaran University.

Hardey, Michael. 1998. The Social Context of Health. 1998. Buckingham: Open University Press.

Hinojosa, Ramon, Craig Boylstein, Maude Rittman, Melanie Sberna Hinojosa, and Christopher A. Faircloth. 2008. "Constructions of Continuity after Stroke." Symbolic Interaction 31 (2), pp. 205-224.

Iba, La. 2005. Hubungan antara Komunikasi dari Paramedis dengan Sikap Pasien Rawat Inap Mengenai Layanan Perawatan: Studi 
pada Layanan Perawatan Medis Rumah Sakit Umum Daerah Propinsi (RSUP) Sulawesi Tenggara [The Relations between Paramedic Communication and Patients' Attitudes about Health Care Services: A Study of Medical Health Care Services in the Public Hospital in the Southeast Sulawesi Province]. Unpublished Master's Thesis Padjadjaran University.

Kadri. 2007. Transformasi Identitas dan Konstruksi Komunikasi Tunanetra: Studi Fenomenologi pada Tunanetra Penghuni Panti Sosial Bina Netra "Wyata Guna" Bandung Mengenai Kebutaan di Usia Dewasa.[Identity Transformation and the Communication Construction of the Blind: A Phenomenological Study of the Blind Living in the Social Institution "Wyata Guna" Bandung Who Became Blind in Their Adulthood]. Unpublished Doctoral Dissertation Padjadjaran University.

Kovarsky, Dana, Allan Shaw, and Maureen Adingono-Smith. 2007. "The Construction of Identity during Group Therapy among Adults with Traumatic Brain Injury." Communication \& Medicine 4(1), pp. 53-66

Lee, Chul-Joo. 2008. "Does the Internet Displace Health Professionals?" Journal of Health Communication 13, pp. 450-464.

Marks, David F., Michael Murray, Brian Evans, and Carla Willig. 2000. Health Psychology: Theory, Research and Practice. London: Sage.

Musgrove, Frank. 1977. Margins of the Minds. London: Methuen.

Nguyen, Hanh Thi. 2006. "Constructing 'Expertness': A Novice Pharmacist's Development of Interactional Competence in Patient Consultations." Communication \& Medicine 3(2), pp. 147-160.ai

Primack, Brian A., Jaime Sidani, May V. Carroll, and Michael J. Fine. 2009. "Associations Between Smoking and Media Literacy in College Students." Journal of Health Communication 14, pp. 541-555.

Robinow, M., G.F. Johnson, and J. Apesos. 1986. "Robin Sequence and Oligodactyly in Mother and Son." American Journal of Medical Genetics 25, pp. 295-297.

Scharf, Barbara F. and Marsha L. Vanderford. 2003. "Illness Narratives and Social Construction of Health." In Teresa L. Thompson, Alicia M. Dorsey, Katherine I. Miller, and Roxanne Parrott, eds. Handbook of Health Communication. Mahwah, NJ: Lawrence Erlbaum Associates, pp. 9-34.

Schutz, Alfred. 1972. The Phenomenology of the Social World. London: Heinemann Educational Book.

Teja, Mohammad. 2006. Stigma dan Komunikasi, Kehidupan Masyarakat Sembuh Kusta: Studi Kasus di Komplek Rumah Sakit Kusta Sinatala, Tangerang, Banten [Stigma and Communication of A Post Leprosy Community: A Case Study in the Sinatala Leprosy Hospital Tangerang]. Unpublished Master's Thesis Padjadjaran University.

Turnpenny, P.D., J.C.S. Dean, P. Duffty, J.A. Reid, and P. Carter. 1992. "Weyer's Ulnar Ray/Oligodactyly Syndrome and the Association of Midline Malformations with Ulnar Ray Defects." Journal of Medical Genetics 29, pp. 659-662.

Verderber, Rudolph F. 1996. Communicate! Eighth Edition. Belmont: Wadsworth.

Vittoria, Anne K. 1999. "Our Own Little Language: Naming and the Social Construction of Alzheimer's Disease." Symbolic Interaction 22 (4), pp. 361-384. 